\title{
African swine fever virus: persistence and diagnostics
}

\section{LABORATORY DIAGNOSTICS OF CHRONIC AND ASYMPTOMATIC FORMS OF AFRICAN SWINE FEVER}

\section{A.D. SEREDA, O.A. DUBROVSKAYA, A.R. IMATDINOV, O.M. STRIZHAKOVA, A.P. VASIL'EV, I.P. SINDRYAKOVA, A.V. LUNITSIN}

All-Russian Institute of Veterinary Virology and Microbiology, Federal Agency of Scientific Organizations, 1, ul. Akademika Bakuleva, pos. Vol'ginskii, Petushinskii Region, Vladimir Province, 601120 Russia, e-mail sereda$56 @$ mail.ru

Received May 17, 2016

\section{Abstract}

African swine fever (ASF) caused by African swine fever virus (ASFV) of Asfivirus genus, Asfarviridae family, can occur in peracute, acute, subacute, chronic or asymptomatic form. At early stages of epizootics, the infection usually occurs in its acute form eventually becoming chronic and/or asymptomatic. Seven to ten days post infection the survived pigs develop virus-specific antibodies which persist for a long time. An assumption is reasonable that in the near future, due to repeated passaging ASFV in wild boar populations in European countries, the ASFV isolates may appear which will cause chronic or asymptomatic rather than the acute forms of the disease. In our study we compared different tests to find those the most effective to reveal latent carriers when no apparent symptoms of the disease observed. Thus, our research was aimed at investigation of some special aspects of the laboratory diagnostics of chronic and asymptomatic forms of ASF. The chronic form of the disease was observed in a pig experimentally inoculated with an attenuated ASF virus Stavropol 01/08 $\mathrm{A}_{4} \mathrm{~S}_{2} / 9 \mathrm{k}$ (at passage 33) at a dose of $10^{6.0} \mathrm{HAU}_{50}$. On day 5 to 7 post inoculation the signs typical of chronic forms of the infection were registered including depression and fever up to $40.5{ }^{\circ} \mathrm{C}$. The antiviral antibody was detected in the swine blood serum from day 7 . After the animal was killed on day 21, a haemadsorption assay revealed ASF virus present at low titers in spleen and mandibular lymph node samples while in liver and lung samples it was not found. Based on the results of polymerase chain reaction (PCR), the viral DNA was determined in the mandibular lymph node sample only. Furthermore, immunoblotting assay identified ASF antibody titers of 1:20 to 1:160 in all the organs examined. The asymptomatic forms of ASF were observed in a wild boar yearling which has been intramuscularly inoculated with an attenuated ASF virus strain MK-200 at a dose of $10^{7.0} \mathrm{HAU}_{50}$. The antiviral antibody was observed in the wild boar serum from day 8 . After the animal was killed on day 25, no pathological signs typical of ASF were found, nor was ASF virus found in the organ samples examined using haemadsorption assay or its DNA was detected in PCR. In immunoblotting assay, virus-specific antibodies were identified in liver, spleen, lung and mandibular lymph node samples at dilutions of 1:40 to 1:320. The opportunity of detecting antibodies in spleen, lung and/or liver samples facilitates the monitoring for ASF to be carried out under the infection control campaigns, especially with respect to wild boars shot in game husbandries. Animals sequentially infected with an ASFV low-virulent isolate and a virulent one can survive, in which case it is quite possible to diagnose the disease using both PCR and serological methods. For making laboratory diagnosis of ASF chronic and/or asymptomatic forms, as well as carrying out monitoring studies, serological methods are recommended.

Keywords: African swine fever, chronic and asymptomatic forms of infection, laboratory diagnostics, immunoblotting

African swine fever (ASF) is a contagious septic viral disease of pigs, characterized by fever, toxicity signs, hemorrhagic diathesis and high mortality rates. Domestic pigs and wild boars are susceptible to ASF regardless of the breed or age. The disease may be hyper-acute, acute, sub-acute, chronic or asymptomatic. The disease is caused by a large coated cytoplasmic virus (African swine fever virus, ASFV; family Asfarviridae, genus Asfivirus) with doublestranded DNA - the only Asfarviridae representative characterized by a substantial 
plurality of biological and genetic features [1-3]. As there is yet no vaccine against ASF, the measure to liquidate and prevent the spread of this disease is a total slaughter of pigs in the so-called first threatened zone, and strict quarantine measures in the second threatened zone [4]. To make decisions on liquidating the ASF outbreaks, laboratory diagnostics is crucial: isolating and identifying the virus by hemadsorption test, identifying the viral genome by PCR method, determining viral antigens by direct immunofluorescence test or by enzyme-linked immunosorbent assay, recognizing virus specific antibodies by indirect immunofluorescence test, indirect enzyme-linked immunosorbent assay, indirect immunoperoxidase assay, and immunoblotting assay [5-8].

There are grounds to believe that due to high ASFV passaging in populations of wild boars in European countries, isolates may appear in the near future that will cause not the acute form, as is currently the case, but chronic or asymptomatic form of the disease. Generally, 7-10 days after the introduction of infection the surviving pigs develop virus specific antibodies that preserve during a long time [9, 10]. Consequently, identifying specific antibodies to ASFV may be the key factor in diagnosing chronic and asymptomatic disease forms. It is the identification and subsequent slaughter of seropositive pigs that lay at the basis of the ASF eradication strategy on the Iberian Peninsula [11]. After ASF eradication in Spain and Portugal, PCR was developed that is now extensively used in laboratory practice [12].

In this work we summarize the results of our comparative laboratory study of organs, blood and blood serum of animals using various methods. It was conducted because of the necessity to determine the most efficient methods of identifying the virus carriers in case of chronic and asymptomatic ASF forms and to substantiate the tactics of diagnostics and monitoring. To that end, the said disease forms were reproduced experimentally by corresponding ASFV strains or variants.

The purpose of this work was to diagnose chronic and asymptomatic forms of African swine fever by hemadsorption test (HAT) and serologic tests - indirect immunofluorescence test (IIFT), enzyme-linked immunosorbent assay (ELISA), immunoblotting assay (IBA), and PCR.

Techniques. Large White pigs (30-50 $\mathrm{kg}$ of live weight) were received from the experimental animal breeding sector (Russian Research Institute of Veterinary Virology and Microbiology), and the young-of-the-year wild boar was acquired at the hunting farm «Pokrovskoye» (Vladimir region). The feeding and keeping met the standards and requirements for the animals' age groups; the slaughter was humane.

The ASFV strains were Mosambic-78 (M-78, genotype V, seroimmunotype III, 6.5-7.5 $\mathrm{lg} \mathrm{HAU}_{50} / \mathrm{cm}^{3}$ ), attenuated MK-200 (derived from M-78, 7.0$7.5 \mathrm{lg} \mathrm{HAU} \mathrm{H}_{50} / \mathrm{cm}^{3}$ ) and Stavropol 01/08 (genotype II, seroimmunotype VIII, 6.0-6.5 $\mathrm{lg} \mathrm{HAU}_{50} / \mathrm{cm}^{3}$ ) attenuated after 33 passages in $\mathrm{A} 4 \mathrm{C} 2 / 9 \mathrm{k}$ cell culture $[13,14]$. The viruses were obtained from the Strain Museum of the Russian Research Institute of Veterinary Virology and Microbiology.

The processing serum and tissue samples (10\% suspensions), HAT, indirect ELISA and IIFT were performed in accordance with RF State Standards (GOST 28573-90 «Pigs. Methods of laboratory diagnostics of African swine fever» and instructions to test systems. In serologic tests and PCR we used commercial kits. For IBA a prototype of immunoblotting test system for serological diagnosis of African swine fever (ASF), based on the highly purified recombinant p30 was used $[15,16]$. All test systems was manufactured by the Russian Research Institute of Veterinary Virology and Microbiology.

Results. Chronic and asymptomatic ASF were caused experimentally using 
attenuated strains and isolates [17, 18].

The pig No. 1 was challenged intramuscularly with the attenuated Stavropol 01/08 $\mathrm{A}_{4} \mathrm{C}_{2} / 9 \mathrm{k}$ at a single dose of $10^{6.0} \mathrm{HAU}_{50}$. On the days 5-7 after the inoculation the animal demonstrated a depressed state with a fever of up to $40.5{ }^{\circ} \mathrm{C}$, which is characteristic of the chronic infection. In IIFT, the titer of specific blood antibodies was 1:2, 1:8, 1:64 and 1:64 on days 7, 9, 14, and 21 , respectively. In IBA, antibodies to ASFV p30 protein were identified at 1:4, 1:32, 1:128 and 1:1024 on days 7, 9, 14 and 21 . In HAT, on day 21 after slaughter we found low titers of ASFV at in spleen and sub-mandibular lymph nodes, but not in liver or lungs. PCR confirmed the presence of viral DNA only in the sub-mandibular lymph nodes. In all organs tested by IBA the titers of antibodies were from 1:20 to 1:160 (Table 1).

1. A comparison of various methods of ASF diagnostics in animals experimentally challenged with attenuated ASFV strains

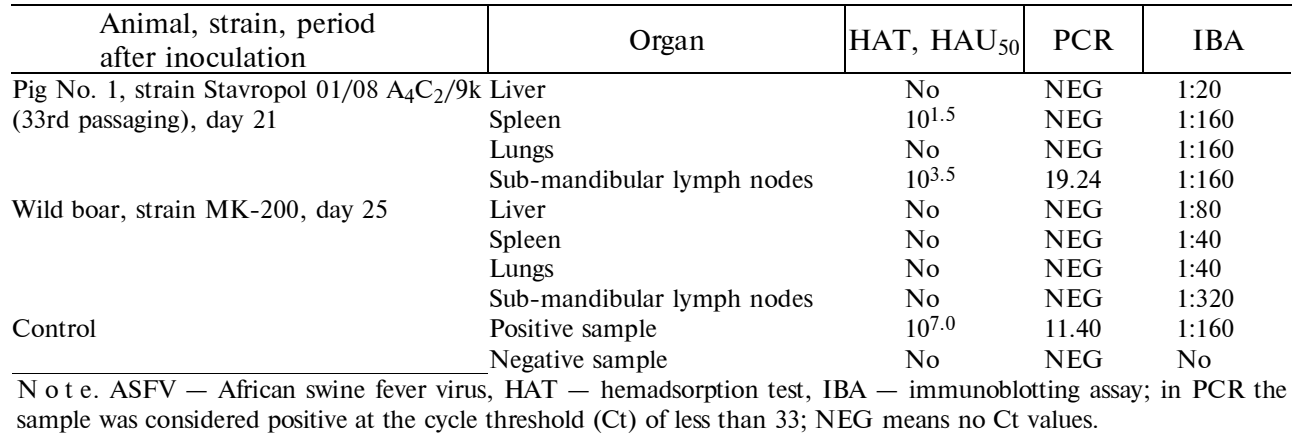

2. A comparison of various methods of ASF diagnostics in animals experimentally challenged with the attenuated (MK-200) and virulent (M-78) ASFV strains

\begin{tabular}{|c|c|c|c|c|c|}
\hline \multirow{2}{*}{ Animal } & \multirow{2}{*}{ Organ } & \multirow{2}{*}{ PCR } & \multicolumn{3}{|c|}{ Antibody titer } \\
\hline & & & indirect ELISA & IIFT & IBA \\
\hline \multirow[t]{4}{*}{ Pig No. 2} & Liver & 21.05 & $1: 320$ & $1: 20$ & $1: 640$ \\
\hline & Spleen & 26.06 & $1: 320$ & $1: 40$ & $1: 320$ \\
\hline & Lungs & 21.05 & $1: 320$ & $1: 80$ & $1: 640$ \\
\hline & Sub-mandibular lymph nodes & NEG & $1: 160$ & $1: 40$ & $1: 320$ \\
\hline \multirow[t]{4}{*}{ Pig No. 3} & Liver & 25.95 & $1: 160$ & $1: 20$ & $1: 320$ \\
\hline & Spleen & 23.57 & $1: 160$ & $1: 20$ & $1: 320$ \\
\hline & Lungs & 25.66 & $1: 320$ & $1: 40$ & $1: 640$ \\
\hline & Sub-mandibular lymph nodes & NEG & $1: 80$ & $1: 40$ & $1: 160$ \\
\hline \multirow[t]{2}{*}{ Control } & Positive sample & 23.35 & $1: 160$ & $1: 20$ & $1: 160$ \\
\hline & Negative sample & NEG & No & No & No \\
\hline
\end{tabular}

The asymptomatic ASF developed in the young-of-the-year wild boar challenged intramuscularly with the attenuated strain MK-200 at $10^{7.0} \mathrm{HAU}_{50}$. In ELISA, the titers of specific antibodies were 1:2, 1:64 and 1:1024 on days 8, 14 and 24, respectively. Antibodies to protein p30 were identified by IBA at 1:8, 1:512 and 1:2048 on days 8, 14 and 24. Post mortem examination on day 25 did not reveal changes characteristic of ASF. HAT revealed no ASFV in the tissue samples, and PCR revealed no viral DNA either. IBA allowed us to identify antibodies in all organs at the titers of 1:40 to 1:320 (see Table 1).

When low-virulent isolates emerge and disseminate among susceptible livestock, there is a probability that animals will survive after their subsequent infection with a homological virulent isolate [19-21]. Therefore, it is essential to know the capabilities of laboratory ASF diagnostics methods.

In this regard, we challenged the pigs No. 2 and No. 3 intramuscularly 
with attenuated strain MK-200 at $10^{6.0} \mathrm{HAU}_{50}$. For 16 days after the inoculation there were no clinical signs of the disease recorded. On day 17, the animals were inoculated intramuscularly with virulent strain M-78 $\left(10^{3.0} \mathrm{HAU}_{50}\right)$. For days 22 to 24 , the pig No. 2 demonstrated the clinical signs characteristic of ASF (depressed state, temperature up to $41.3{ }^{\circ} \mathrm{C}$, lack of appetite, hemorrhage on the ears and on the belly), and there were no symptoms in the pig No. 3. After an additional intramuscular inoculation of the pig No. 3 with M-78 (105.0 HAU50) on day 25, the characteristic symptoms developed from days 28 to 30 (depressed state, lack of appetite, fever up to $41.4{ }^{\circ} \mathrm{C}$ and hemorrhage on the ears and on the belly). During the period when the clinical signs manifested, the phosphonoacetic acid $\left(20 \mathrm{~cm}^{3}\right)$ was administrated intramuscularly to guarantee the survival of the pigs No. 2 and No.3. Table 2 shows the results of post mortem examination of the pigs No. 2 and No .3 on day 38 .

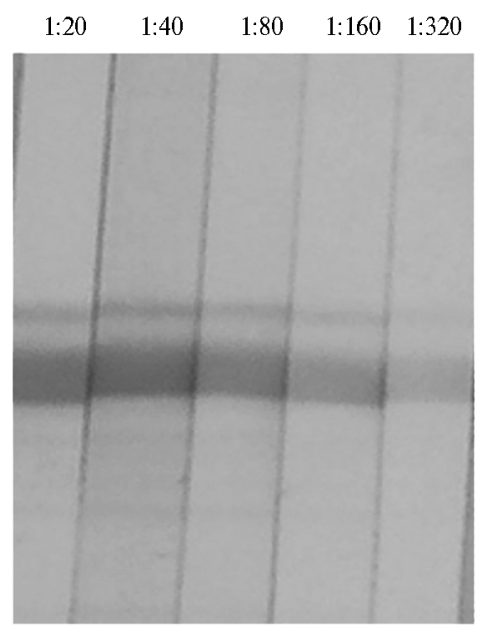

Blotting of virus specific antibodies in $10 \%$ suspension of sub-mandibular lymph node tissue of the pig No. 3 inoculated with the attenuated (MK-200) and virulent (M-78) ASFV strains (sample dilutions indicated).

According to PCR, the viral genome was identified in the tested organs, except for submandibular lymph nodes. Virus specific antibodies were detected in all organs. Their highest titers we identified in the lungs. Analytical sensitivity of IBA was superior to ELISA, and its results were demonstrative and easily documented (Fig.).

According to published data, in pigs experimentally challenged with attenuated ASFV strains the virus isolation from blood and tissue is possible for a limited time. Particularly, in the animals infected intramuscularly with the attenuated ASFV strains FK-32/135 or E-70MC at

$10^{6.5}-10^{7.5} \mathrm{HAU}_{50}$ the authors [22] rarely identified the infectious virus only on days 4 to 7 in blood and in $10 \%$ spleen tissue suspension in the titers of 1.0$2.0 \mathrm{lg} \mathrm{HAU}_{50} / \mathrm{cm}^{3}$.

The study of the distribution and accumulation of the FK-32/135 strain in the organs and tissues of pigs after intramuscular or aerosol inoculation at $10^{6.5}-10^{7.0} \mathrm{HAU}_{50}$ proved that on day 7 the ASFV remained only in the lungs, bronchial and mediastinal lymph nodes, and after 10 days it was isolated only from the parotid lymph node. At a later time, the infectious virus could not be isolated from the animal organs or tissues [23]. The study of ASFV distribution in gilts inoculated intramuscularly with a higher dose of the attenuated strain MK-200 $\left(10^{8.50} \mathrm{HAU}_{50}\right)$ showed that on days 7 to 14 it was identified in blood and $10 \%$ suspension of liver, spleen, lungs, sub-mandibular and bronchial lymph nodes tissues in the titers of 3.0-4.0 lg $\mathrm{HAU}_{50} / \mathrm{cm}^{3}$. On days 21-30 after the inoculation, the virus was detected only in blood samples and in $10 \%$ suspension of liver and spleen (the titers of 1.0-1.5 lg $\mathrm{HAU}_{50} / \mathrm{cm}^{3}$ ) [24]. After 2 months, no virus could be isolated from the animals' blood samples [25]. These data evidence that due to the protection mechanisms induced by the attenuated ASFV strains, the amount of the infectious virus and its components in the pig organs may be substantially reduced for a relatively short period.

Therefore, our research shows that 3 weeks after the animals are infected with the attenuated strain or variant of ASFV, a reliable positive result in HAT (infectious virus identification) or PCR (viral DNA detection) is difficult to obtain 
(false negative results are possible). In this case, definite diagnosis is ensured by serologic tests that make it possible to identify virus specific antibodies in blood and tissues of pigs and wild boars. Under restrictive measures, the possibility to detect antibodies in spleen, lungs and liver tissues makes the ASF monitoring substantially easier, especially for wild boars acquired from hunting farms. The test system for ASFV serologic diagnostics by IBA has some advantages, such as high analytical sensitivity and no need for special equipment. Serologic methods may be expanded to analyze saliva [26]. In the territories with registered ASF epizooty, there is a probability of simultaneous circulation of both low-virulent and virulent homological virus isolates. Animals consistently infected with lowvirulent and then with virulent isolates can survive. In this, infected animals can be identified both by PCR and by serologic methods.

Thus, this research shows that detection of infectious African swine fever (ASF) virus by hemadsorption or its genome by PCR using animal blood and tissues is ineffective for diagnostics and monitoring of chronic or asymptomatic ASF forms due to possible false negative results. Reliable data can be obtained by serologic methods. A small number (one to dozen) of samples should be analyzed by immunoblotting.

\section{REFEREN CES}

1. Dixon L.K., Costa J.V., Escribano J.M., Rock D.L., Vinuela E., Wilk i n s o n P.J. Family Asfarviridae. M.H.V.V. Regenmortel (ed.). London Academic Press, San Diego, CA, 2000: 159-165.

2. S e re d a A.D., B a ly s h e v V.M. Voprosy virusologii, 2011, 4: 38-42 (in Russ.).

3. M a k a rov V.V., S u k h a rev O.I., T S v e t n o va I.V. Veterinarnaya praktika, 2013, 1(60): 6-16 (in Russ.).

4. Khomenko S., Beltrán-Alcrudo D., Rozstalnyy A., Gogin A., Kolbasov D., Pinto J., Lub roth J., Martin V. African swine fever in the Russian Federation: risk factors for Europe and beyond. EMPRES watch, 2013, 28: 1-14. Available http://www.fao.org/docrep/018/aq240e/aq240e.pdf. No date.

5. Manual of diagnostic tests and vaccines for terrestrial animals. Chapter 2.8.1. African swine fever. Office International des Epizooties, Paris, France, 2012. $7^{\text {th }}$ ed. Available http://www.oie.int/fileadmin/Home/fr/Health_standards/tahm/2.08.01_ASF.pdf. No date.

6. S a n c he z-Viz c a i n o J.M. African swine fever diagnosis. In: African swine fever. Y. Becker (ed.). Martinus Nijhoff, Boston, USA, 1987: 63-71.

7. Vishnyakov I.F., M it in N.I., Karpov G.M., Ku rinnov V.V., Yashin A.T. Veterinariya, 1991, 4: 28-31 (in Russ.).

8. Perez-Filgueira D.M., Gonzalez-Camacho F., Gallardo C., ResinoTalavan P., Blanco E., Gomez-Casado E., Alonso C., Escribano J.M. Optimization and validation of recombinant serological tests for African swine fever diagnosis based on detection of the p30 protein produced in Trichoplusia ni larvae. J. Slin. Microbiol., 2006, 44(9): 114-3121 (doi: 10.1128/JCM.00406-06).

9. Re is A.L., Parkhous e R.M.E., Penedos A.R., Martins C., Le it ão A. Systematic analysis of longitudinal serological responses of pigs infected experimentally with African swine fever virus. J. Gen. Virol., 2007, 88: 2426-2434 (doi: 10.1099/vir.0.82857-0).

10. S e r e d a A.D., K a z a k o va A.S., I m a t d i n o v A.R., K o l b a s o v D.V. Humoral and cell immune mechanisms under African swine fever (review). Agricultural Biology, 2015, 50(6): 709-718 (in Engl., in Russ.) (doi: 10.15389/agrobiology.2015.6.709eng, doi: 10.15389/agrobiology.2015.6.709rus).

11. Cubillos C., Gumez-Sebastian S., Moreno N., Nunez M.C., MulumbaMfumu L.K., Que mbode C.J., Heath L., Etter E.M.C., Jori F., Escri b a n o J.M., B 1 a n c o E. African swine fever virus serodiagnosis: A general review with a focus on the analyses of African serum samples. Virus Res., 2013, 173: 159-167 (doi: 10.1016/j.virusres.2012.10.021).

12. Ste ig e r Y., A c k e rma n n M., Met t raux C., Ki h m D.U. Rapid and biologically safe diagnosis of African swine fever virus infection by using polymerase chain reaction. J. Clin. Microbiol., 1992, 30(1): 1-8.

13. Malogolovkin A., Burmakina G., Titov I., Sereda A., Gogin A., Baryshnikova E., Kolbasov D. Comparative analysis of African swine fever virus genotypes 
and serogroups. Emerging Infectious Diseases, 2015, 21(2): 312-315 (doi: 10.3201/eid2102.140649).

14. Balyshev V.M., Kalantaenko Yu.F., Bolgova M.V., Prudnikova E.Yu. Doklady Rossiiskoi akademii sel'skokhozyaistvennykh nauk, 2011, 5: 52-53 (in Russ.).

15. Kazakova A.S., Sereda A.D., Strizhakova O.M., Zhivoderov S.P., Lys ka V.M., Balyshev V.M., Morgunov Yu.P., Shubina N.G., Khukhorov a I.Yu., K o lb a s o v D.V., G u s e v A.A. Veterinariya, 2014, 9: 52-56 (in Russ.).

16. Afonso C.L., Alcaraz C., Brun A., Sussman M.D., Onisk D.V., Escribano J.M., Rock D.L. Characterization of p30, a highly antigenic membrane and secreted protein of African swine fever virus. Virology, 1992, 189(1): 368-373 (doi: 10.1016/00426822(92)90718-5).

17. Kolbas o v D.V., B a ly s he v V.M., S e red a A.D. Veterinariya, 2014, 8: 3-8 (in Russ.).

18. Balys heva V.I., Prudnikova E.Yu., Gal'nbek T.V., Balys hev V.M. Doklady Rossiiskoi akademii sel'skokhozyaistvennykh nauk, 2015, 1-2: 65-69 (in Russ.).

19. Ruiz-Gonzalvo F., Carne ro M.E., B ru y e l V. Immunological responses of pigs to partially attenuated African swine fever virus and their resistance to virulent homologous and heterologous viruses. Proc. CEC/FAO Research Seminar «African Swine Fever», Sardinia, Italy. P.J. Wilkinson (ed.). EUR 8466 EN. Luxemburg, Belgium, Commission of the European Communities, 1981: 206-216.

20. Vigario I.D., Te r rinh a A.M., N un es J.F.M. Antigenic relationships among strains of African swine fever virus. Archiv für die gesamte Virusforschung, 1974, 45(3): 272-277 (doi: 10.1007/BF01249690).

21. King K., Chapman D., Argilaguet J.M., Fishbourne E., Hutet E., Cariolet R., Hutchings G., Oura C.A., Netherton C.L., Moffat K., Taylor G., Le Potier M.F., Dixon L.K., Tak a matsu H.H. Protection of European domestic pigs from virulent African isolates of African swine fever virus by experimental immunization. Vaccine, 2011, 29: 4593-4600 (doi: 10.1016/j.vaccine.2011.04.052).

22. Nepoklonov E.A., Z e le nt sov V.A., Re utova E.G., Kurinov V.V. Materialy nauchno-teoreticheskoi konferentsii VNIIVViM [Proc. Sci. Conf. Vet. Virology and Microbiology]. Pokrov, 1981: 242-244 (in Russ.).

23. K o r o m y lov E.V. Tezisy nauchnoi konferentsii VNIIVViM [Proc. Sci. Conf. Vet. Virology and Microbiology, Pokrov]. Pokrov, 1984: 244-246 (in Russ.).

24. Kotel'nikov A.P., Petrov Yu.I., Z e lentsov V.A., Re utova E.G. Materialy nauchno-teoreticheskoi konferentsii VNIIVViM [Proc. Sci. Conf. Vet. Virology and Microbiology]. Pokrov, 1981: 151-152 (in Russ.).

25. Pet rov Yu.I., Kot e l'nikov A.P., M it i n N.I., C Heryat nikov L.L., T a t a r i n t s e va N.T. Tezisy nauchnoi konferentsii VNIIVViM [Proc. Sci. Conf. Vet. Virology and Microbiology]. Pokrov, 1985: 24-27 (in Russ.).

26. Mur L., Gallardo C., Soler A., Zimmermman J., Pelayo V., Nieto R., Sá n c he z-Vizcaíno J.M., Aria s M. Potential use of oral fluid samples for serological diagnosis of African swine fever. Vet. Microbiol., 2013, 165(1-2): 135-139 (doi: 10.1016/j.vetmic.2012.12.034).

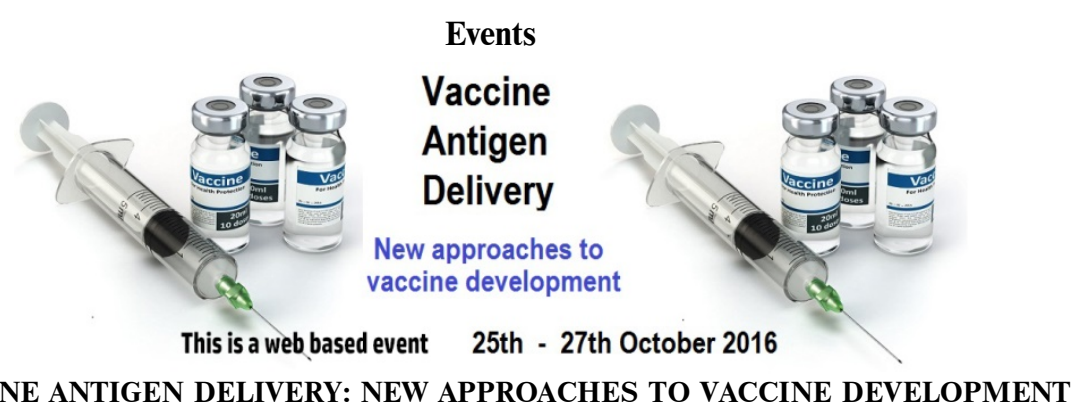

VACCINE ANTIGEN DELIVERY: NEW APPROACHES TO VACCINE DEVELOPMENT (25-27 October 2016, ONLINE-INTERNATIONAL, United Kingdom)

Contact: http://lifescienceevents.com/vaccine2016/

Information: http://www.globaleventslist.elsevier.com/events/2016/10/vaccine-antigen-delivery-new-approaches-to-vaccine-development/ 